\title{
THE BELL-MAGENDIE-WALKER CONTROVERSY
}

\author{
by
}

\section{GILLIAN RICE*}

\begin{abstract}
Alexander Walker, like his eminent contemporaries Sir Charles Bell and François Magendie, spent many years of his life studying cerebral and spinal cord anatomy. Walker's efforts, however, unlike those of Bell and Magendie, did not secure him a place in medical history except for an occasional mention as a peripheral figure in the so-called Bell-Magendie controversy. In this nineteenth-century dispute both protagonists claimed priority for the discovery that the anterior spinal roots are motor and the posterior roots sensory. Each man gathered loyal supporters, and in subsequent years they carried on the battle for honours on behalf of the central disputants. Alexander Walker joined neither camp: he took a unique stance, attacking the claims of both Bell and Magendie, and denying to either the honour of priority. Walker's protestations have commonly been regarded as the rantings of an eccentric. Little attention has been paid to his theories concerning the nature and role of science, but an understanding of Walker's wider beliefs makes it clear why he bitterly contested the view of spinal root function proposed by his contemporaries. A detailed study of the dispute and his life reveal that as much was at stake for him as for Bell and Magendie, and that this matter of priority, which is usually regarded as a two-man controversy, was, in fact, a three-man battle. This article will deal briefly with the ideas and experiments of Bell and Magendie around which the dispute centred, and will then concentrate on aspects of Walker's life and work which make his role in the controversy both intelligible and meaningful.

In the early 1800 s, Charles Bell focused his research energies on a study of the brain. With his teleological outlook, absorbed from his brother John and from Alexander Monro secundus, Bell looked closely at brain structure in order to determine its function. He noted that the spinal cord, like the brain, had distinct anterior and posterior portions; by tracing the crura of the cerebrum and cerebellum into the spinal cord he established their connexions with the anterior and posterior fasciculi respectively. ${ }^{1}$ He postulated that the double root of the spinal nerves might be the means by which both cerebral and cerebellar functions could be conveyed to all parts of the body: ${ }^{2}$ the cerebrum being responsible for the operations of the mind (the "higher" functions of modern terminology), the cerebellum controlling the viscera ("vital" functions such as heartbeat and respiration) and uniting the actions of various parts of the body.
\end{abstract}

\footnotetext{
*Gillian Rice, MB, ChB, MRCP, MRCGP, MPhil., 53 Selsdon Road, London SE27 OPQ.

${ }^{1}$ Charles Bell, Idea of a new anatomy of the brain, 1811 , reprinted in G. Gordon-Taylor and E. W. Walls, Sir Charles Bell; his life and times, Edinburgh and London, E. \& S. Livingstone, 1958, p. 225.

2 Ibid., p. 226.
} 
Bell looked for a way of proving the difference in function between the cerebrum and cerebellum. It occurred to him that, because of the connexions he had shown to exist between the spinal columns and parts of the brain, touching the extension of the spinal marrow in the spinal nerve roots was a way of indirectly "touching" the cerebrum and cerebellum, and thus of finding out more about their functions. ${ }^{3}$ Bell carried out his ingenious idea in the following way. He first either stunned or killed an animal, cut through the vertebrae, and exposed the roots of the spinal nerves. He then sectioned the posterior roots and observed that no motion of the muscles resulted. On touching the anterior roots, however, the relevant part was immediately convulsed. Since Bell already had a picture in his mind of the anterior roots conveying sensation to, and motion from, the cerebrum, the inducement of convulsions by touching the anterior root was to be expected. The cerebellum, having no role in sensibility or muscular motion, should in no way be affected by touching or sectioning its connexions in the posterior roots. For Bell, these experimental results provided unequivocal proof of the validity of his "new anatomy of the brain".

Bell circulated privately amongst his friends his New idea of the anatomy of the brain but did not make the work generally available to the public; it seems likely that by lecturing rather than publishing his ideas, he hoped to attract increasing numbers of pupils to his own anatomy school. In subsequent years, Bell's research and experiments centred on his long-standing interest in the nervous supply to the face. His animal experiments stimulating and sectioning the nerves of the face served to confirm his view of the trigeminal nerve as the highly "sensible" nerve responsible for facial sensation and mastication, whereas the "insensible" portio dura of the seventh nerve (the facial, or seventh cranial, nerve of modern classification) controlled the muscles of expression, associated with other muscles of the body involved in respiration, and hence termed by Bell the "respiratory nerve" of the face. ${ }^{4}$ Bell delivered these ideas in two papers to the Royal Society in July 1821 and May 1822; in August 1821, knowing this material was soon to be published, he deliberately sought applause from the French physiologists, amongst whom Magendie was pre-eminent, by sending John Shaw (his brother-in-law and assistant) to. Paris to publicize his system of classifying nerves.

Magendie witnessed Shaw's demonstrations of Bell's facial nerve experiments and may well have learnt something about Bell's earlier work on the spinal nerve roots. Whether Magendie had already contemplated animal experiments to investigate spinal nerve root function remains contentious, but we know that after Shaw's visit he was actively engaged in such work. In June 1822, Magendie opened the unossified vertebral columns of live puppies to expose the posterior spinal nerve roots. First, he cut the posterior using small scissors, sutured the skin overlying the area and then observed the puppy. ${ }^{5}$ This approach was different from Bell's, for the latter had noted the immediate effect of touching or sectioning a nerve root. Magendie probably expected, as Bell had suggested, that sensation and ordinary motion were conveyed by a single nerve root,

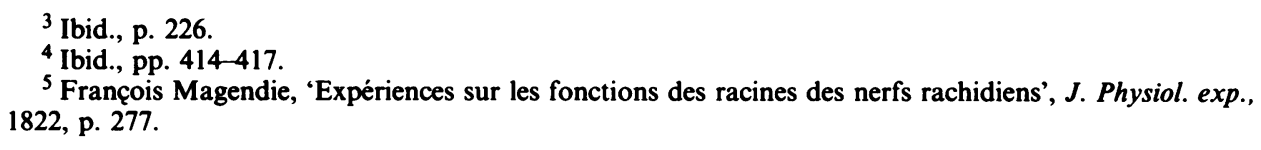




\section{Gillian Rice}

and that, if impaired, they would both be so to the same extent. However, he was surprised to find that the corresponding limb became insensible to puncture and strong pressure while movement remained unimpaired. ${ }^{6}$ Magendie next sectioned the anterior roots, leaving the posterior roots intact; he observed that the relevant limb became paralysed but retained normal sensation. Finally, he cut both roots together and noted loss of movement and sensation. ${ }^{7}$ The results convinced Magendie that the posterior roots primarily conveyed sensibility, and the anterior roots were more especially concerned with movement.

Bell read the account of Magendie's work published in July 1822 and realized that the roles Magendie had assigned to each of the spinal nerve roots must be correct. Bell's feelings were mixed, however: he acknowledged the conclusions as Magendie's but believed that they had been revealed only by use of an experiment which Bell regarded as his own. Reaction from Bell and his loyal followers was swift: Shaw wrote to Magendie pointing out that Bell had also sectioned the spinal nerve roots some thirteen years earlier, and in order to assess such claims more fully Magendie read a copy of the New anatomy of the brain obtained from Shaw. ${ }^{8}$ In October 1822, Magendie publicly acknowledged Bell as the first person to conduct the nerve root experiments but maintained that Bell had not realized the distinct roles of the anterior as motor, and posterior as predominantly sensory, roots, the discovery of which remained rightly his alone. 9

In the ensuing priority dispute Bell backed up his claim by publishing in 1824, An exposition of the natural system of the nerves of the human body with several editions over subsequent years. All the editions contained a republication of the 1821 papers delivered by Bell to the Royal Society. The "republished" works were, in fact, subtly altered by Bell to make his conclusions correspond with Magendie's findings and, at the same time, to give the impression that he had demonstrated and published these results by 1821 , having been aware of them since his experiments in $1809 / 10$, well in advance of Magendie. Since it was these republications that were most accessible and most commonly referred to by physiological writers in Britain, it is understandable that many were inclined to believe Bell's version of events.

Alexander Walker was one contemporary of Bell who was in no way prepared to accept his point of view concerning the dispute. Although Magendie's claims certainly incensed Walker, his reaction was not prompted by any sympathy for Bell. Walker declared that his own work on the function of the spinal nerve roots had preceded that of both Bell and Magendie, and their later efforts merely "borrowed, inverted, and blundered about" 10 a portion of a much more extensive and significant system which had occupied him since his youth.

Walker, born in Leith, Scotland, in 1779, was some five years younger than Bell. Of his family and childhood nothing is known, but he received sufficient education to

\footnotetext{
6 Ibid., p. 277.

${ }^{7}$ Ibid., pp. 278-279.

${ }^{8}$ François Magendie, 'Expériences sur les fonctions des racines des nerfs qui naissent de la moelle épinière', J. Physiol. exp., 1822, 2: 370.

9 Ibid., p. 371.

${ }^{10}$ Alexander Walker, The nervous system, anatomical and physiological, London, 1834, p.v.
} 


\section{The Bell-Magendie-Walker controversy}

proceed, at the age of eighteen, to the Medical School of Edinburgh University. For two years he studied anatomy with John Barclay, from whom he absorbed a teleological approach to the subject, a belief in comparative anatomy for investigating the human body, and a fervent dislike for subjecting animals to cruelty for the sake of physiological experimentation. Indeed, Walker considered animal experiments to be an inappropriate form of investigation for physiological matters. The complexity and obscurity of body processes at atomic and molecular levels convinced him that animal experiments could not render conclusions certain. On all but one occasion, Walker was to remain true for thirty years to his repudiation of experiments, faithful instead to the methods of observation and reasoning.

Walker was not only an eager student of anatomy: he had a voracious hunger for knowledge in a vast range of subjects. He read widely on philosophy, general physics, natural history, politics, and history. He was inspired by the words of Francis Bacon, and impressed by Machiavelli's Il Principe. He admired both men as brilliant philosophers; both had achieved lasting fame and respect on account of their profound insights into the nature of man and society. Walker dreamed of the dizzy heights which he himself might reach if his knowledge, wisdom, and reasoning could surpass even these two "giants".

Walker's extensive reading of various "sciences" convinced him that their separation into different categories was artificial. He viewed "science" as a body of factual knowledge gathered over time, providing insight both into man and the world around him. Since Walker saw these two spheres as being intimately related, he also believed that "facts" in different sciences must be interconnected, and that this interdependence could be shown to exist if only a correct arrangement of the facts were to be formulated. Walker believed such a system to be crucial for the advancement of man; it would show more clearly the value of individual discoveries, how each discovery could influence sciences other than that in which it was traditionally categorized, and the potential for beneficial application to the Arts. Walker spent several years working with obsessional enthusiasm on his magnum opus-a plan he entitled 'The natural system of universal science'.

Walker's 'Natural system', first published in 1809, provided the method by which investigation of the Universal Science could be most profitably undertaken. A knowledge of matter, its motions and qualities (Walker's 'Metaphysics') must first be acquired, then of 'General Physics' (such as astronomy, geography, magnetism, and meteorology). Walker advised that one should then proceed to 'Particular Physics' (the "consideration of the less or more particular objects in nature"), which included chemistry, botany, anatomy, and physiology. Walker believed a knowledge of the structure and functions of the brain to be the key to an understanding of the remaining departments of the Universal Science, viz. literature, morals, and politics. Only with a knowledge of the "intellectual organs" could one understand man's interaction with the world around him. The brain received impressions from the external world, and from such impressions stemmed sensation, understanding, ideas, emotions, and other "intellectual functions", including reasoning and judgement. Such intellectual functions were the basis of all man's creative communication (literature and the fine arts), his individual actions and their consequences (morals), and the action of nations 


\section{Gillian Rice}

(history and politics). Walker saw the brain as the organ which received and responded to information from the outside world and which dictated all man's social behaviour. He intended his Natural System to increase man's scientific knowledge and, like Bacon, he proposed that all such knowledge should be usefully applied. Walker was particularly eager to understand cerebral anatomy and function, for such insight would provide "the short and sure remedy for the greatest moral, civil, and political evils" 11 and would secure for himself recognition as a philosopher even greater than his illustrious predecessor Bacon. ${ }^{12}$

Walker never graduated in medicine; almost certainly he was too absorbed with anatomical work and with his concept of Universal Science to bother continuing with medical studies. At the age of twenty, he went to London where he was associated with the anatomist John Abernethy at St Bartholomew's Hospital. ${ }^{13}$ Around the year 1799, he was introduced to the successful surgeon Anthony Carlisle at the house of a mutual "philosophic friend". Carlisle attempted to dissuade Walker "from the cultivation of science . . . as an unprofitable path-the road only to ruin" 14 but his convictions were set and his ambitions already immutable.

Walker immersed himself in cerebral dissections. By 1803, his knowledge of brain structure led him to conclude that the function of will or volition could be assigned to the cerebel (cerebellum), ${ }^{15}$ and he continued to work to define the role of other parts of the brain. His method of investigation was " 1 st, accurately to ascertain structure, and to observe healthy phenomena; and 2ndly, to recur to comparative anatomy and physiology"16 - lessons well learnt from Barclay. From facts one could suggest a rational hypothesis and, if new facts were confirmatory, an acceptable theory could be developed. Walker continued to reject the use of experiments, and deliberately excluded them from his investigative method.

In 1807, Walker returned to Edinburgh where he earned a living by lecturing. Some of his lectures were on anatomy and physiology and were attended by students and medical practitioners; he also gave lectures in the Assembly Rooms to mixed audiences "On general and particular science". ${ }^{17}$ In all his lectures he expounded the principles of his Universal Science and illustrated its applications in such courses as The outline of a natural system of medical science, published in Edinburgh in 1808. This was a period of furious industry for Walker: he carried out cerebral dissections at every opportunity, assisted by John Lizars (then apprenticed to John Bell) and he was eagerly compiling articles for the most ambitious project of his life-a journal of his own creation, the Archives of Universal Science.

When he launched the Archives in January 1809, Walker intended it to replace all other journals for artificially-separated sciences, and to serve as a source of education

\footnotetext{
11 Ibid., p. iii.

12 Various parts of Walker's 'Natural System' were explained in detail in a number of his publications between 1809 and 1841 but I believe that the overall plan (as outlined in the paragraph above) was formed in his mind as early as 1798 .

${ }_{13} \mathrm{~J}$. Struthers, Historical sketch of the Edinburgh Anatomical School, Edinburgh, 1867, p. 77.

14 Walker, op. cit., note 10 above, p. iii.

15 Ibid., p. 28.

16 Ibid., p. 3.

${ }^{17}$ Struthers, op. cit., note 13 above, p. 77.
} 
(at a reasonable cost) to the public. ${ }^{18} \mathrm{He}$ did not direct the journal at any particular professional group, but instead had a wider audience in mind; he wanted all members of society to change the way they thought about science and he intended the Archives to be the instrument inducing such changes. These intentions to modify science were paralleled by Walker's enthusiastic support for parliamentary reform. In each of the first three issues of the Archives he devoted considerable space to his own articles on 'History of the period, with political reflexions', in which he applauded contemporary efforts for reform of parliament and advocated the need "resolutely to reform our military system".19 For Walker, "the only method according to which social improvements can be carried on with sufficient prospect of an auspicious event is when the improvement of our institutions advances, in a just proportion to the illumination of the public understanding", ${ }^{20}$ and he saw himself as the wise philosopher who would initiate the necessary public education.

Sadly, his dreams were soon shattered, for after only three issues the Archives ceased publication, almost certainly because the journal failed to sell. It was a rude blow for Walker; presented with his masterful plan for the expansion of knowledge and the betterment of mankind, the public had remained unimpressed and decided that seven shillings and sixpence every quarter could be better spent on other things. Letters dated 1809-12 from Walker to Charles Stewart (the university printer producing the Archives, and also his good friend and benefactor) chronicle Walker's financial woes, which were to plague him for the rest of his life. ${ }^{21}$ Despite these setbacks, Walker continued to work tirelessly on cerebral anatomy, and in the months between January and April of 1809 he reached new conclusions, associating the spinal cord with the cerebellum in the production of volition, and proposing a "proper division ... into nerves of sensation and nerves of volition". The difference between these two sets of nerves was that "their motions take place in different directions. The latter, therefore, may be said to resemble arteries; the former, the veins". ${ }^{22}$

Walker developed this analogy of a "circulation" of the nervous system in the July issue of the Archives, tracing the "course of nervous action" through the brain. This followed a pathway of medullary matter which ran from the organs of sense, passing to the spinal marrow via the anterior bundles of the spinal nerves, which Walker therefore termed nerves of sensation. The medullary fibres continued through the anterior columns of the spinal cord, eventually reaching the cerebral hemispheres. They continued from the white matter of the hemispheres to the cerebellum and then descended through the posterior columns of the spinal marrow to the posterior bundles of the spinal nerves, which Walker termed the nerves of volition. ${ }^{23}$ This concept of an ascending, sensory pathway and a descending course conveying volition formed the basis of all Walker's future work on the function of different parts of the brain, and was confidently made public in the third and final number of the Archives.

\footnotetext{
18 Alexander Walker, Archives of Universal Science, 1809, 1: xl.

19 Ibid., 2: 332.

20 Ibid., 1: 217.

${ }^{21}$ Lawrence King, Dictionary of Scientific Biography, p. 129, n. 5.

22 Walker, op. cit., note 18 above, 1809, 2: 191 .

23 Ibid., 3: 173-174.
} 


\section{Gillian Rice}

Walker was no doubt disappointed, frustrated, and quite probably embittered following the failure of his cherished project. Such emotions, and his continued financial difficulties, may have played a part in deciding him to return to London some time during the next few years. He was induced to write to the editor of the Annals of Philosophy in 1815 when he read a claim in that journal, by a Dr John Cross of Glasgow, to discoveries "similar" to his own concerning the cerebellum and spinal nerve roots. In the March number, a Dr Leach declared that the work of Gall and Spurzheim was the original source of these discoveries, and Walker promptly wrote claiming that such facts were never stated in the works of these authors and that his own work had pre-dated Dr Cross's by some six years. ${ }^{24}$ Although subsequent issues of the Annals contained an exposition of Walker's ideas at greater length, ${ }^{25}$ again the public ignored his work and it seems that finally Walker lost heart. He abandoned efforts to publicize the Universal Science and gave up the cerebral dissections which had formed such a fundamental part of the enterprise.

Walker's activities and whereabouts during the 1820 s are something of a mystery. Struthers ${ }^{26}$ maintained that he was involved with several newspapers, and was an active founder of the Literary Gazette (which dated from 1817). Names of the editorial staff were not listed in the magazine, but a reply to a correspondent in the number for 29 March 1817, criticizing Magendie's animal experiments, showed a style similar to Walker's and was signed "W". Thus it is possible that Walker was then employed by the Literary Gazette and it would make sense for him to have moved into a literary sphere, for this was the next area to be explored according to his sytem for Universal Science. We can be virtually certain that he was no longer actively engaged in work on cerebral anatomy for if he had been, he would most definitely have responded promptly to the claims of Bell and Magendie in 1822. Instead, it seems that his interest and energy were directed elsewhere, and for some period of time he was also absent from England-journeying to Paris and other regions of France. ${ }^{27}$ It may have been these travels that stimulated his interest in a new area which was to occupy more and more of his attention-physiognomy-and, in particular, different national characteristics. The useful application of anatomical knowledge to physiognomy may also have re-confirmed his belief in the principles laid down in the Natural System of Universal Science. After a gap of some fourteen years, Walker's next publications were short essays on the 'Character of the French', 'Comparison of the modern with the ancient Romans', and 'Character of the English, Scots and Irish' in Blackwood's Magazine in 1829. He began to prepare several books on physiognomy and female beauty and this work rekindled his interest in cerebral anatomy because he believed that facial characteristics were determined by the relative proportions of various parts of the brain, particularly the cerebrum and cerebellum. Walker's convictions concerning the different mental functions for which the cerebrum and cerebellum were

\footnotetext{
${ }^{24}$ Alexander Walker,, 'On the use of the cerebellum and spinal marrow', Ann. Phil. 1815, 5: 316-317.

${ }^{25}$ Alexander Walker, 'Sketch of a general theory of the intellectual functions of man and animals, given in reply to Drs Cross and Leach', ibid., 1815, 6: 23-24 and 118-124.

${ }^{26}$ Struthers, op. cit., note 13 above, p. 77.

27 In his book Physiognomy founded on physiology, and applied to various countries, professions, and individuals (1834), Walker makes mention of impressions gathered during previous visits to the provinces of Picardie and Artois as well as Paris (pp. 109 and 155).
} 


\section{The Bell-Magendie-Walker controversy}

responsible also led him to explain racial temperament and talents according to racial differences in cerebral anatomy.

By 1833, Walker was busy preparing his book Physiognomy founded on physiology, and applied to various countries, professions, and individuals, a work that inter alia discussed at some length the author's views on the role of the cerebellum. In July of that year, Dr William C. Henry presented a report to the British Association assembled at Cambridge, part of which discussed the Bell-Magendie controversy. On its publication, Walker saw the report and was enraged when he read that "the honour of this discovery, doubtless the most important accession to physiological knowledge since the time of Harvey, belongs exclusively to Sir Charles Bell!"28 Walker had good reason to feel bitter and envious toward Bell: a man of similar age, with the same kind of anatomical training, Bell had achieved wealth and success as a scientist and surgeon whereas Walker's path seemed destined for nothing but obscurity and debt. Walker could not bear to see Bell claim more scientific honours in an area so closely related to his own unrecognized work of the early 1800 s. He therefore determined to redress the balance; he would expose the plagiarism of which Bell and Magendie were both guilty in his eyes, and he would rightfully be credited with the discovery of the distinct functions of the anterior and posterior spinal nerve roots. Walker decided to repeat his cerebral dissections to be certain he had made no mistakes, and then planned to publish all his ideas on the functions of the brain which formed such an integral part of his concept of the Universal Science.

Walker soon had his book on physiognomy finished and then devoted himself to cerebral dissection and extensive reading on the scientific literature which he had ignored for so many years. He paid particular attention to the German physiologists such as Tiedemann and the Wenzels, whose reliance on observation and comparative anatomy closely paralleled his own investigative approach. He wrote to John Lizars informing him of his current work and probably asked him to verify formally the dissections he had witnessed and been assistant to, as far back as 1807. It may well have been at this stage that Walker conducted the only experiment of his life. He was told (perhaps by Lizars) that the public would never believe his ideas unless he backed them up with experimental "evidence". ${ }^{29}$ Walker reluctantly opened the spinal canal of a frog and noted that irritation of the anterior roots caused motion while that of the posterior roots caused little or none. ${ }^{30}$ Since Walker believed that without sensation, whether "conscious" or "inconscious", there was no motion in animals, he expected motion to result from stimulation of the anterior (his sensory) roots, but not from the posterior (his voluntary motor) roots. Although the experiment was superficially very similar to Bell's and Magendie's, because Walker's concept of nervous system function was so different, he interpreted his observations in a way quite unlike that of both his contemporaries, proving to him the validity of the ideas which he already held. As Cranefield has pointed out, ${ }^{31}$ Walker's arguments were highly logical, but lacking further information on the ease of excitability of sensory and motor fibres, he was able

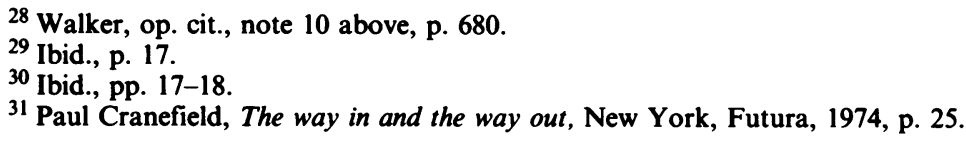


to draw conclusions quite different from those of Bell and Magendie from an experiment technically akin to theirs.

By May 1834, Walker had begun to write his book on the nervous system. The preface included a historical account of his own ideas and work from as early as 1803 , with a vitriolic attack on Bell, and to a lesser degree Magendie, for their later plagiarism and "inversion" of his theory of spinal root functions. Walker's bitter criticism of Bell and Magendie centred around four main grievances: (1) their failure to acknowledge his $1808 / 9$ publications, which clearly assigned the functions of sensation and volition to different spinal nerve roots, in advance of such theories of their own; (2) their inferior reasoning, which led them to "invert" his theory, assigning sensory functions to the posterior roots and motor functions to the anterior roots; (3) their methods of physiological investigation, principally their reliance on experimental evidence. ${ }^{32} \mathrm{He}$ emphasized the distortion produced by the experimental situation, alleging that injury (such as sectioning the nerve roots) could produce "only the grossest deception, for as the injury is compound, the effect cannot be the simple one sought for"; 33 (4) their erroneous conclusions resulting from their narrow approach to particular parts of the nervous system. If, like him, they had taken a more general view, Walker believed that they would have realized the impossible implications of their "inverted" interpretation of spinal nerve root functions.

All four points served to defend and solicit support for Walker's Natural System of Universal Science. Being denied priority for assigning a distinct function to each of the spinal nerve roots robbed Walker of scientific acclaim, but even more devastating was the import of the "inversion" of his proposed nerve root functions. A denial of this basic premise made a mockery of his reliance on observation and reasoning. Reversing the functions he had assigned to the nerve roots nullified the analogous functions attributed to the cerebrum and cerebellum. That, in turn, undid all Walker's extended theories on intellectual functions, which were utterly dependent on the role of the cerebrum in perception and of the cerebellum in volition. Likewise, his explanations of individual and racial physiognomy would have disappeared in an instant since they were related to the ratio of cerebral to cerebellar proportions and the predominance of function which Walker took such proportions to infer. Walker's book The nervous system, anatomical and physiological was indeed much more than a battle for priority-it was a desperate bid to gain support for the Natural System of Universal Science, to justify Walker's life work, which otherwise seemed destined to sink without trace.

Walker worked furiously and by July had nearly completed the entire work. At this late stage of the enterprise, he read an anonymous article in the Edinburgh Medical and Surgical Journal ${ }^{34}$ which suggested that Bell had had access to Bellingeri's 1818 treatise

\footnotetext{
32 Bell would have bitterly resented being labelled an "experimentalist". He claimed that he delayed for a long time before doing spinal cord experiments on live rabbits because of "the unpleasant nature of the operation" (Bell, An exposition of the natural system of the nerves of the human body, 1824, reprinted in Cranefield, op. cit., note 31 above, p. 29) and thereafter stunned the animals in order to make it a less cruel procedure. It is true, though, that his reluctance to perform vivisectional work did not prevent him from conducting numerous experiments on the facial nerves of asses and dogs during the early $1800 \mathrm{~s}$.

${ }^{33}$ Walker, op. cit., note 10 above, p. 96.

34 Anonymous untitled "critical analysis" of three publications by Bellingeri, Edinb. med. surg. J., 1834, 42: $111-138$.
} 


\section{The Bell-Magendie-Walker controversy}

on the facial nerves (from the library of the Royal Society) and had plagiarized his work. Not only did this increase Walker's contempt for Bell, but it prompted him to question the originality of Bell's "inverted" theory of spinal nerve root function. Walker realized that Bell may have stolen Magendie's 1822 ideas in the same way as he believed Bell had plagiarized his own work and Bellingeri's. Walker re-examined Bell's original 1821 and 1822 papers in the Philosophical Transactions and realized that in neither did he express the ideas which Magendie had published in July 1822. Walker hurriedly wrote an appendix to his book, explaining his recent discoveries and decrying Bell's deceitful behaviour with regard to both Bellingeri and Magendie. Although Walker pointed out that it was not until the "republished" papers appeared in Bell's 1824 edition of his Exposition . . . of the nerves that he adopted Magendie's views, there was neither time nor space to detail any deliberate alterations made in Bell's papers before Walker's book went to press.

Alas for Walker, his Nervous system won no converts to his view of the brain, and he resigned himself once more to applying the principles of the Universal Science to other areas-physiognomy, pathology and therapeutics, and morals. In the mid-1830s, another priority dispute arose, between the German, Johannes Müller, and the Englishman, Marshall Hall, over the discovery of the spinal reflex. Walker despised Müller's use of animal experiments and realized that publication of an objective account of the work on the spinal reflex, showing the folly of such reliance on experiments, would give him an opportunity to produce a similar account of the spinal nerve root work and likewise prove the mistakes of the "experimentalists" Bell and Magendie.

Walker gathered together all the relevant material by Bell, Magendie, and himself (as well as those involved in the spinal reflex debate). He then had an opportunity to point out in more detail the deliberate additions and emendations that Bell had made to the "republished" Phil. Trans. papers. He also made generally available for the first time the full text of Bell's Idea of the new anatomy of the brain. Walker published Documents and dates of modern discoveries in the nervous sytem anonymously in 1839 , but two years later openly referred to the book as his own. ${ }^{35}$ Whether it convinced anyone that Bell did not deserve priority over Magendie remains doubtful, but in later years certain authors such as Austin Flint ${ }^{36}$ gave Walker credit for being the first to propose that motion and sensation were conveyed by different spinal nerve roots.

In his introduction to the facsimile of Walker's Documents and dates, Cranefield ${ }^{37}$ indicated the importance of this work in the history of the so-called Bell-Magendie controversy. Other historians have been less sympathetic in their assessment of Walker's significance to the debate, and Clarke relegated his works as "biased

\footnotetext{
${ }^{35}$ Alexander Walker, Pathology founded on the natural system of anatomy and physiology, London, 2nd ed., 1841, p. 1 of 'Mr Walker's anthropological works'.

${ }^{36}$ Austin Flint jun., 'Historical considerations concerning the proportions of the roots of the spinal nerves', Quart. J. Med. med. Jurisprudence, October 1868, reprinted in Cranefield, op. cit., note 31 above, p. 626.

${ }^{37}$ Paul Cranefield, Documents and dates of modern discoveries in the nervous system by Alexander Walker-A facsimile of the original edition, London, 1839- with an introduction by Paul F. Cranefield, Metuchen, N. J., Scarecrow Reprint Corporation, 1973, p. iv.
} 


\section{Gillian Rice}

polemics promoting personal theories and of little value to the historian". ${ }^{38}$ This closer look at Walker's life-work and his part in the spinal nerve root debate emphasizes that there were three men whose work produced three superficially similar experiments, the conclusions from which indicated their three very different points of view. This study of the controversy also shows the important contributions that Walker made to a full historical understanding of the dispute: he was the first to point out the deliberate alterations made by Bell to his "republished" Phil. Trans. papers, and he also made available to the general public the full text of Bell's Idea of the new anatomy of the brain. The motivation for Walker's part in the polemic lay in his unshakable commitment to the philosophy underpinning his Natural System of Universal Science. Walker's view of spinal nerve root function was an integral part of his theories concerning "science", man, and the physical world, and it is only with an understanding of these wider beliefs that we can make sense of his isolated stand in the dispute.

38 E. Clarke, in M. Neuburger, The historical development of experimental brain and spinal cord physiology before Flourens, transl. and ed., with additional material, by Edwin Clarke, Baltimore and London, Johns Hopkins University Press, 1981, p. xviii. 